\title{
The Role Of Non Market Capability Moderation In The Relationship Between Environment, Strategies, And Performance: A Study On "Pdam" (Water Supplier Companies) In Sulawesi
}

\author{
Mursalim \\ Department of Management, Faculty of Economic, Hasanuddin University, Makassar, Indonesia
}

\begin{abstract}
This study aims to: 1) explain the influence of government involvement and resources on the efficiency and performance of Water Supplier Companies; 2) explain the role of non market capability moderation in the relationship between environment, strategies, and the performance of Water Supplier Companies. The data were collected by using a survey on 60 Water Supplier Companies in Sulawesi. From those companies, 54 gave consent to participate in this study, but only 50 questionnaires can be analysed by using PLS. This reserach reveals that: 1) financial support from the local government was on time, and the water production capacity and distribution wereon optimal level; 2) the financial supportwas strengthened by the ability of the Water Supplier Companies to communicate with local government; and 3) the availability of resources - including pipe networks, machines, and pumps - suited the necessity.
\end{abstract}

Keywords:Government involvement, Resources, Non market capability, Efficiency, and Performance

\section{Introduction}

Organisation performance is one of the most important variables in management research. It is even the most important indicator in the performance of an organisation (Gavrea et al., 2011). There have been many researches on the relationship between environment, strategies, and performance, although the results are different. Some researchers, such as Mavondo and Farrel (2003) use the elements of external environment as the variabels that determine company performance. In terms of government involvement as one of external environment elements, Tian (2001) found that company value decreases when the government involvement is low, and vice versa. On the other hand, Chen et al. (2005) found that higher government involvement in a company leads to lower performance of the company. Similarly Sun and Tong (2003), and Vong and Lin (2005) found that government involvement by having share in a company has a negative effect on the company performance.

Some companies, especially those with government capital such as BUMN (State-owned Company) and BUMD (Local Government-owned Company), are required to have non market capability to enable them to influence public policy, or to increase the negative effects of market on the companies. Non market capability describes the internal process, resources, and company knowledge in relation with political activities that are not distributed among the companies (Baron, 2003; Hillman et al., 2004, William, 2005).

Non Market capability can be realized through communication with executive and legislative officials and other stakeholders. For example communication and lobbying can be done in order to adjust the current rates, or in relation with government involvement in the programs of technical and management support through local government commitment and participation in the form of fund sharing in the investment of Water SupplierCompanies. Furthermore, non market capability can be also found in the involvement of professional institutions such as univeristies to strengthen the planning of Water SupplierCompany. This research aims to analyse the factors determining the performance of Water Supplier Companies from environmental point of view, including non market capability and strategy.

\section{Conceptual Framework and Hypothesis}

\subsection{Government Involvement, Efficiency, And Performance}

The role of strategy in the relationship between company environment and performance is important (Li, 2001; Mavondo and Farrel, 2003). Government involvement is a form of environment that needs analysis and serious attention in designing strategies to improve performance (Christmann, 2004; Chen et al., 2005). The results of Xu et al. (2005) about politicians' control, agency problems, and company performance in China reveal that organisations will be able to improve their performance if the managers have autonomy in making decisions about business operation and human resource development. Besides, the improvement of company performance can be achieved if state ownership of the company is low. 
Internal environment (such as technology and financial resources) that is owned and controlled can improve companies' performance (Lee et al., 2001; Hill et al, 2004). In resource based point of view (Penrose, 1959; Rumelt, 1991; Barney, 1991; and Grant, 1991) internal environment that influences company performance can be divided into resources and competencies (Man and Wafa, 2008). In a concentrated industry, Bonardi et al. (2005) found that the more a company depends on government regulations, the better the development of the company will be. Government support in the form of supply of suitable resources A company will improve the ability of the company to operate efficiently and effectively. Therefore:

Hypothesis 1: The higher government involvement is, the higher the performance of Water Supplier Companies will be.

Hypothesis 2: The higher government involvement is, the higher the efficiency of Water Supplier Companies will be.

Hypothesis 3: Efficiency can mediate the influence of government involvement on the performance of Water Supplier Companies.

\subsection{Resources, Non Market Capability, efficiency, and performance}

Companies will respond to any change happens in external environment (non market environment) by taking proportional actions (passive reaction, positive anticipation, and public policy shaping) (Weidenbum in Hillman and Hitt, 1999; Baron,2003). Environment factor has an important role in a company, especially in choosing the orientation and formulation of company strategies. Changes of environment, either externally or internally, require company capability to quickly adapt tothe changes so that the company can still survive and be competitive (Penrose, 1959; Porter, 1980; Barney, 1991; Peteraf, 1993).

These actions are usually called political actions, which occur only when companies have diynamic capability, such as non market capability developed by resources (Holburn and Zelner, 2010) that can improve company performance (Thompson and Strickland, 2003). In RBV view, dynamic organisation capability will make the company efficient and effective (Ambrosini et al., 2009; Easterby-Smith et al., 2009). William (2005) says that companies that have imperfect environment, such as disadvantageous political pressure, will develop non market capability, rather than market capability because with non market capability, the company can minimize threats or negative effects of policies so that the performance of the company can be improved (Schwark, 2009), and vice versa. Therefore:

Hypothesis 4: $\quad$ Non market capability can moderate the influence of government involvement on the performance of Water Supplier Companies.

Hypothesis 5: The better the resources are, the higher the performance of Water Supplier Companies will be.

Hypothesis 6 :

Hypothesis 7 :

Hypothesis 8 :

The better the resources are, the more efficient the Water Supplier Companies will be.

Efficiency can mediate the influence of resources on the performance of Water Supplier Companies.

The more efficient a Water Supplier Company is, the higher its performace will be.

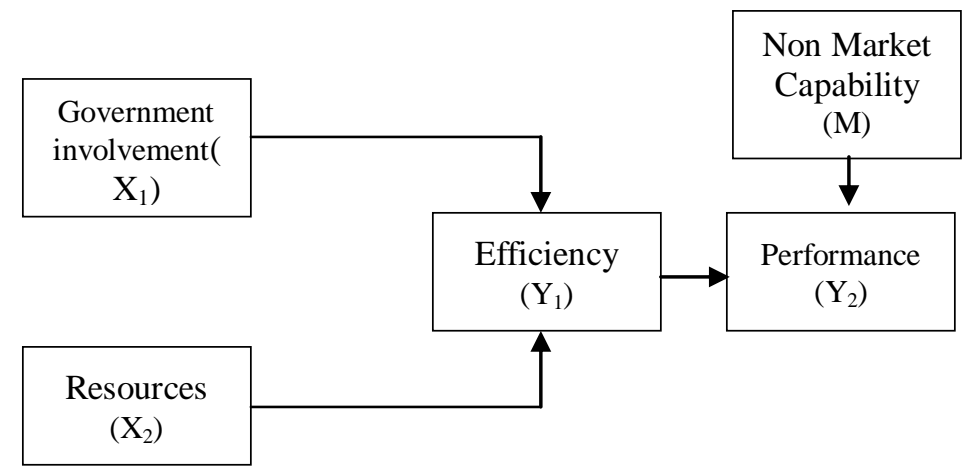

Figure 1: Conceptual Framework

\section{Research Methodology}

The analysis unit of this study is Water Supplier Company (PDAM). The population included all Water Supplier Companies in Sulawesi (60 companies). The samples were selected by using census method. The respondents were the managing directors from each company who have been in the position for at least 2 years. 
The data were collected by using questionnaires and interviews with some main directors or functional directors. The testing of the proposed model used inferential statistical analysis techniquewith variance based Structural Equation Modeling (SEM) known as Partial Least Square (PLS) method (Solimun, 2010).

\section{Research Findings}

\section{Research Findings and Discussion}

Hypothesis testing between the variables of government involvement, resources, efficiency, and non market capability can be seen in Tables 1-3 and chart 2 . The tables show the path coefficient value, T-statistic, p-value, and the significance values of each variable.

Table 1 The results of analysis of direct influence

\begin{tabular}{|l|c|c|c|c|l|}
\hline \multicolumn{1}{|c|}{ Independent variables } & $\begin{array}{c}\text { Dependent } \\
\text { variables }\end{array}$ & $\begin{array}{c}\text { Path } \\
\text { Coefficient }\end{array}$ & $\begin{array}{c}\text { T- } \\
\text { Statistic }\end{array}$ & P-Value & Remark \\
\hline $\begin{array}{l}\text { Governmentinvolvement } \\
\left(\mathrm{X}_{1}\right)\end{array}$ & $\begin{array}{c}\text { Efficiency } \\
\left(\mathrm{Y}_{1}\right)\end{array}$ & 0,541 & 6,011 & $<0,001$ & Significant \\
\hline $\begin{array}{l}\text { Governmentinvolvement } \\
\left(\mathrm{X}_{1}\right)\end{array}$ & $\begin{array}{c}\text { Performance } \\
\left(\mathrm{Y}_{2}\right)\end{array}$ & 0,309 & 3,000 & 0,003 & Significant \\
\hline Resources $\left(\mathrm{X}_{2}\right)$ & $\begin{array}{c}\text { Efficiency } \\
\left(\mathrm{Y}_{1}\right)\end{array}$ & 0,157 & 1,163 & 0,245 & $\begin{array}{l}\text { Non } \\
\text { Significant }\end{array}$ \\
\hline Resources $\left(\mathrm{X}_{2}\right)$ & $\begin{array}{c}\text { Performance } \\
\left(\mathrm{Y}_{2}\right)\end{array}$ & 0,198 & 2,176 & 0,030 & Significant \\
\hline Efficiency $\left(\mathrm{Y}_{1}\right)$ & $\begin{array}{c}\text { Performance } \\
\left(\mathrm{Y}_{2}\right)\end{array}$ & 0,394 & 3,078 & 0,002 & Significant \\
\hline GI*NMC & $\begin{array}{c}\text { Performance } \\
\left(\mathrm{Y}_{2}\right)\end{array}$ & 0,239 & 2,656 & 0,008 & Significant \\
\hline
\end{tabular}

Source: Data processing with PLS

Table 2: The results of analysis of mediation testing and efficiency variable

\begin{tabular}{|c|c|c|c|c|}
\hline & $\begin{array}{l}\text { Original } \\
\text { sample } \\
\text { estimate }\end{array}$ & $\begin{array}{c}\mathrm{T}- \\
\text { Statistic }\end{array}$ & $\begin{array}{c}\text { P- } \\
\text { Value }\end{array}$ & Explanation \\
\hline Governmentinvolvement $\rightarrow$ Performance ${ }^{(a)}$ & 0,309 & 3,000 & 0.003 & $\begin{array}{l}\text { a } \\
\text { Pathcoefficientinfluenceon } \\
\text { the performanceof } \\
\text { government } \\
\text { involvementwith } \\
\text { themediating variable }\end{array}$ \\
\hline${\text { Governmentinvolvement } \rightarrow \text { Efficiency }^{(\mathbf{c})}}$ & 0,541 & 6,011 & $\stackrel{<}{0.001}$ & $\begin{array}{l}\text { c }=\text { Path coefficientthe } \\
\text { influenceof government } \\
\text { involvement on efficiency }\end{array}$ \\
\hline Resources $\rightarrow$ Performance ${ }^{(a)}$ & 0,198 & 2,176 & 0.030 & $\begin{array}{lr}\mathbf{a}=\text { Path coefficientthe } \\
\text { influenceof resourceson } \\
\text { performanceof r with } \\
\text { mediation variable }\end{array}$ \\
\hline Resources $\rightarrow$ Efficiency ${ }^{(\mathbf{c})}$ & 0,157 & 1,163 & 0,245 & $\begin{array}{l}\mathbf{c}=\text { Path coefficientthe } \\
\text { influenceof resourceon } \\
\text { performance ofwithouta } \\
\text { mediating variable }\end{array}$ \\
\hline Efficiency $^{(} \rightarrow$ Performance ${ }^{(d)}$ & 0.374 & 2,833 & 0,005 & $\begin{array}{l}\mathbf{d}=\text { Path coefficientsof } \\
\text { efficiency on the } \\
\text { performance }\end{array}$ \\
\hline
\end{tabular}

Source: Data processing with PLS 
The Role of Non Market Capability Moderation in the relationship between Environment, Strategies,

Tabel 3; The results of analysis of mediation testing

\begin{tabular}{|l|c|c|c|c|c|}
\hline \multicolumn{1}{|c|}{$\begin{array}{c}\text { Independent } \\
\text { variable }\end{array}$} & $\begin{array}{c}\text { Dependent } \\
\text { variable }\end{array}$ & $\begin{array}{c}\text { Path } \\
\text { Coefficient }\end{array}$ & T-Statistic & P-Value & Significance \\
\hline $\begin{array}{l}\text { non } \\
\text { marketCapabilities } \\
(\mathrm{M}) \mathbf{( b}_{\mathbf{2}}\end{array}$ & $\begin{array}{c}\text { Performance } \\
(\mathrm{Y} 2)\end{array}$ & 0,184 & 1,786 & 0,074 & $\begin{array}{c}\text { Non } \\
\text { Significant }\end{array}$ \\
\hline $\begin{array}{l}\text { Regression } \\
\begin{array}{l}\text { Moderation } \\
\left(\text { GI*NMC) } \mathbf{( b}_{\mathbf{3}}\right)\end{array}\end{array}$ & $\begin{array}{c}\text { Performance } \\
(\mathrm{Y} 2)\end{array}$ & 0,239 & 2,656 & 0,008 & Significant \\
\hline
\end{tabular}

Source: Data processing with PLS

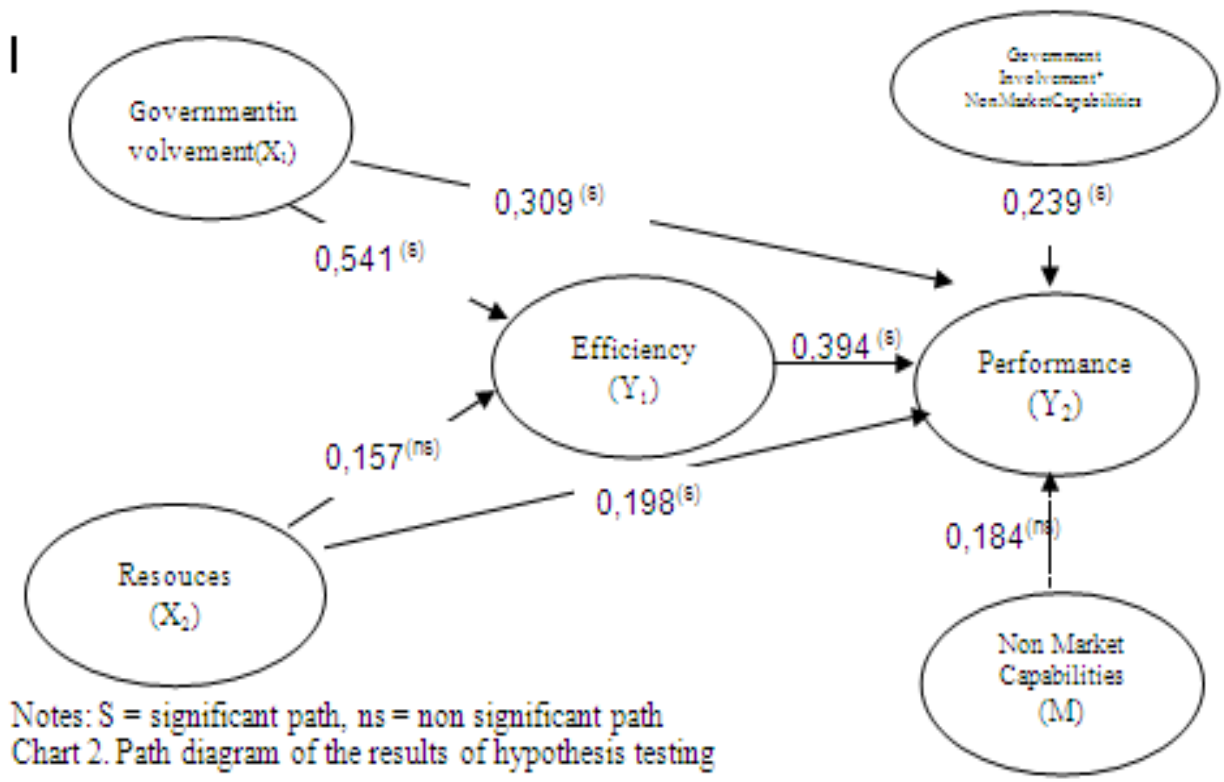

\section{Discussion}

The Influence of Government Involvement on Performance

The result of analysis of the influence of government involvement on performance is significant and positive, which means that the higher the government involvement is (reflected in financial support from the Local Government), the higher the company performance will be (reflected in the decreasing level of water loss) (See table 1). In other words, financial support from the Local Government to Water Supplier Comopanies is able to decrease the level of water loss. This finding is in line with agency theory which assumes that each individual behaves based on his/her own interest. It is assumed that the share holder (Local Government) as the principal has interests, in addition to peformance improvement (financial benefit), in the profit from the investment and non financial benefit such as the availability of drinking water for the community or the improvement of social welfare. Meanwhile, company management expects reward on the performance level it has achieved.

\section{The Influence of Government Involvement on Efficiency}

The influence of government involvement on efficiency is significant and positive (See Table 1). The analysis of measurement model shows that government involvement variable is more dominant as it is reflected in the involvement of Local government in financial support. Meanwhile, efficiency variable is more dominant as it is reflected in the emphasis on the optimization of production capacity and distribution. Therefore, it can be said that financial support given by Local Government to Water Supplier Companies can increase the optimization of production capacity and distribution. Theoretically, the result of this study is in line with Keynes' theory on government involvement (government intervention) in economic activities.

\section{The Influence of Resources on Performance}

The result of analysis of the influence of resources on the performance of Water Supplier Companies in Sulawesi is significant and positive (Table 1). This shows that the hypothesis that "the better the resources are, the higher the performance of the company will be" is accepted. This finding is in line with the study of Hassanein and Khalifa (2006); and Aguilar et.al.,(2009) which found that the performance of Water Supplier 
Companies is influenced by the quality of pipe network, administration process, water availability, and economic and financial continuity.

Meanwhile, Aguilar et.al., (2009) in a research on Water Supplier Company at the border of Mexico and USA found that the performance of the company is influenced by the quality of pipe network, administration process, service coverage, financial continuity, and water availability.

\section{The Influence of Resources on Efficiency}

The result of the analysis of the influence of resources on the efficiency of Water Supplier Companies in Sulawesi is not significant and positive (Table 1). This means that the hyphotesis "the better the resources are, the more efficient the company will be" is rejected. This finding shows that the resources of Water Supplier Companies, as it is reflected in the availability of physical resources such as pipe network and pump machines, is not able to explain the variation in efficiency change in Water Supplier Companies, as it is reflected in the emphasis on production capacity and distribution. This finding does not support RBV theory (Penrose, 1959; Wernefelt, 1984) especially in Water Supplier Company because company resources, especially physical resources such as pipe network, machines, and pumps are not the only factors that determine company efficiency reflected by production capacity and distribution. However, natural resource especially water resource is a determinant factor. Therefore, this research has found a new concept about the factors determining company efficieny, especially in Water Supplier Companies.

\section{The Influence of Efficiency on Performance}

The result of the analysis about the influence of efficiency on the performance of Water Supplier Companies is significant and positive (Table 1). This means that the hypothesis "the more efficient a Water Supplier Company is, the higher its performance will be" is accepted. This confirms a study by Guerrini et al. (2011) which found that efficiency enables a company to get profit or have better prformance. This study also found that private Water Supplier Companies are more efficient compared to government-owned Water Supplier Companies because private companies emphasize more on efficiency since they are profit-oriented.

This research also confirms the research of Tynan and Kingdom (2002) which shows that efficiency influences companies' performance. The study focused on efficiency in making investment, and efficiency in operation and maintainance. This study also found that in addition to efficiency variable, the variables of financial sustainability and quick responses to customers influence performance too.

\section{The Influence of Government Involvement on Performance through Efficiency}

The result of the analysis measuring the indirect influence of government involvement on the performance of Water Supplier Companies mediated by efficency is significant and positive (Table 2). This means that government involvement is able to improve efficiency and with efficiency the performance of Water Supplier Companies will increase. Agency theory and Keynes' theory on government involvement imply that Local Governments have interest in the success of Water Supplier Companies as the suppliers of drinking water. It is mentioned in the Regulation Number 32 of 2004 or the Regulation of the Minister for Internal Affairs Number 13 of 2006 and the Regulation of the Minister for Internal Affairs Number 59 of 2007 that each Local Government has an obligation to conduct programs and activities related to the obligatory activities and optional activities. One of the obligatory activities is in health sector, which includes community access to drinking water with health standard. Meanwhile, government involvement in economic activities can be realized, either in the form of regulations or business entities that will become public service providers to create efficiency. Therefore, this study, which can explain the influence of government involvement on performance mediated by efficiency, confirms the theory of government involvement and agency theory.

\section{The Influence of Resources on Performance through Efficiency}

The result of analysis to measure the indirect influence of resources on the performance of Water Supplier Companies mediated by efficency is positive but not significant (Table 2). This means that company resources are not able to improve efficiency and the performance of Water Supplier Companies. It has been explained previously that duration of use and condition of resources become the factors of inefficiency in Water Supplier Companies. To solve this problem, it is necessary to have human resources with experience and special skills, especially technical or operational skills. People with better skills are needed to fix and maintain some pipe networks that are already in rusty condition. This does not mean that new pipe network will not cause leakage. Many pipe networks had leakage just after they had been operated.

\section{The Influence of Government Involvement on Performance Moderated by Non Market Capability}

The result of testing in determining the influence of non market capability in moderating the influence of government involvement on the performance of Water Supplier Companies in Sulawesi is positive and 
significant (Table 3). This means that non market capability strengthens the influence of government involvement on the performance of Water Supplier Companies. This finding supports the argument proposed by Dahan (2005). The coefficient of each correlation reveals that the moderation can be categorized as pure moderation. Non market capability, which is the ability to conduct effective communication with stakeholders, enables Water Supplier Companies to gain benefit from government involvement. However, in reality it is not easy for each managing director or management staff of Water Supplier Companies to have non market capability. In any Water Supplier Company, optimization of non market capability will be able to become the source of prime service, compared to the other Water Supplier Company.

The success or effectiveness of communication which reflects non market capability should be supported with commitment, integrity, and courage among managing directors and the management of Water Supplier Companies. The occurrence of these elements in the process of communication between Water Supplier Companies and stakeholders will facilitate the realization of non market capability. In this case, government involvement will become a strategic strength for Water Supplier Companies to improve performance.

\section{Conclusions}

\section{Conclusions, Suggestion And Limitations}

1. Financial support from local government for Water Supplier Compnaies is able to improve production capacity and distribution, and decrease the level of water loss.

2. Availability of physical resources, such as pipe network and machines, is able to decrease the level of water loss.

3. Availability of physical resources according to the necessity is not able to improve production capacity and distribution.

4. The increase of optimalization of production capacity and distribution is able to decrease the level of water loss.

5. Government involvement supported by effective communication will increase the performance of Water Supplier Companies.

\section{Recommendations}

1. It is important for regional and city governments to encourage the development og Water Supplier Companies through policies and programs synergized with other stakeholdres, such as Perpamsi, central government, and provincial government.

2. It is important for Water Supplier Companies to pay special attention on the implementation of human asset/resource management practices and asset/resource management, especially physical asset/resource management.

3. It is necessary for Water Supplier Companies to optimize activities oriented toward the creation of efficiency in company operational activities, such as in leakage management and human resource productivity.

\section{Limitation}

1. It was expected that research respondents were the managing directors of Water Supplier Companies, especially the Director or Main Director. However, some directors had busy schedules so that the questionnaires were completed by other functional directors. In such case, some information might not reflect the real condition.

2. The samples were only from Water Supplier Companies in Sulawesi so that it is necessary to replicate the research for the purpose of generalisation beyond the current samples.

\section{References:}

[1] Gavrea ,Corina, Ilieş, Liviu and stegerean, Roxana. 2011. Determinants of organizational performance: the case of romania, Management \& Marketing Challenges for the Knowledge Society Vol. 6, No. 2, pp. 285-300

[2] Mavondo, Felix dan Farrel, Mark. 2003. Cultural Orientation; Its relationships with Market Orientation, Innovation and Organizational Performance. Management Decision. 41/3 pp 241 - 249.

[3] Tian, G. 2001. Government Shareholding and the Value of China's Modern Firm. Working Paper.

[4] Chen, Xuan, Weide Chun dan Xiaoning Zhu. 2005. Government Controlling and Firm Performance: An Empirical Study on China's Listed Companies. Chinese Business Review. Vol 4 No.7

[5] Sun, Q dan W. Tong. 2003. China Share Issue Privatization: The Extent of Its Success. Journal of Financial Economics. Vol. 70 (2) p $183-222$

[6] Vong, Anna P. I. and Lin, Y.J. 2005. Ownership Structure and Corporate Performance of China's Privatized Enterprises. University of Macau. Source: umir.umac.mo/.../3971_0_TConference2008.

[7] Baron, David P. 2003. Business and Its Environment. Fourth Edition. Prentice Hall. USA

[8] Hillman, A., Schuler, D., and Keim, G. 2004. Corporate political activity: A review and research agenda. Journal of Management30: 837-857 
[9] William P. Wan. 2005. Country resource environments, firm capabilities, and corporate diversification strategies. Journal of Management Studies 42: 1 .

[10] Li, Haiyang. 2001. How does new venture strategy matter in the environment-performance relationship? The journal of high technology management research 12 (2001) 183-204

[11] Christmann, Petra. 2004. Multinational Companies and the Natural Environment: Determinants of GlobalEnvironmental Policy Standardization. The Academy of Management Journal, Vol. 47, No. 5 (Oct., 2004), pp. 747-760

[12] Chen, Shaw K, Chen, Xuanjuan, Lin, Bing-Xuan, and Zhong, Rongsa. 2005.The impact of government regulation and ownership on the performance of securities companies: Evidences from China.Global Finance Journal. 16 113-124

[13] Xu, L., Zhu, T. and Lin, Y. 2005. Politician Control, Agency Problems and Ownership Reform: Evidence of China, Economics of Transition 13(1), pp. 1-24.

[14] Lee, Choonwoo, Lee, Kyungmook, and Pennings, Johannes M. 2001. Internal Capabilities, External Networks, and Performance: A Study on Technology-Based Ventures: Strategic Management Journal Vol. 22, No. 6/7

[15] Hill Charles W. L., and Jones, Gareth R. 2004. Strategic Management Theory: An integrated approach. 9th edition. South-Western Cengage Learning

[16] Penrose ET. 1959. The Theory of the Growth of the Firm. Oxford University Press: New York.

[17] Rumelt, R. P. 1991. How Much Does Industry Matter? Strategic Management Journal, 12(3), pp. 167-185.

[18] Barney JB. 1991. Firm resources and sustained competitive advantage. Journal of management. 17(1); 99-120

[19] Grant, Robert M. 1991. The Resource-Based Theory of Competitive Advantage: Implications for Strategy Formulation. California Management Review; Spring 33, 3; ABI/INFORM Global pg. 114

[20] Man, Mok Kim and Wafa, Syed Azizi. 2008. The Relationship between Distinctive Capabilities, Innovativeness, Strategy Types and The Performance of Small And Medium-size Enterprises (SMEs) of Malaysian Manufacturing Sector. the 13th Asia Pacific Management Conference, Melbourne, Australia, 2007, 11-19

[21] Bonardi, J.P., Hillman, A., and Keim, G. 2005. The attractiveness of political markets: Implication for firm strategy. Academy of Management Review. 30 (2): 397-413.

[22] Hillman, A. J., \& Hitt, M. A. 1999. Corporate political strategy formulation: A model of approach, participation, and strategy decisions. Academy of Management Review, 24(4): 825-842.

[23] Porter, Michael E. 1996. What Is Strategy? Harvard Business Review. November - Desember 1996. Page $61-78$.

[24] Holburn, Guy.L.F dan Bennet A. Zelner. 2010. Political Capabilities, Policy Risk, And International Investment Strategy: Evidence From The Global Electric Power Generation Industry. Strategic Management Journal 31: 1290-1315

[25] Thompson Jr, Arthur A and Strickland, A.J.. 2003. Strategic Management; Concept and Cases. McGraw Hill Irwin.

[26] Ambrosini, V., Bowman, C. and Collier, N. 2009. Dynamic Capabilities: An Exploration of How Firms Renew Their Resource Base. British Journal of Management, Volume 20, No. S1, pp. S9-S24.

[27] Easterby-Smith, M., Lyles, M.A. and Peteraf, M.A.2009. Dynamic Capabilities: Current Debates and Future Directions. British Journal of Management, Vol.20 pp. S1-S8.

[28] Schwark, Bastian. 2009. Toward a Contingent Resource-Based View of Nonmarket Capabilities under Regulatory Uncertainty.Centre for European Policy Studies, Brussels, Belgium

[29] Solimun. 2010. Pemodelan Persamaan Struktural; Pendekatan PLS dilengkapi dengan Pembahasan Variabel Moderator. Program Studi Statistika FMIPA Program Doktor Ilmu Manajemen FE Universitas Brawijaya. Malang

[30] Hassanein, A. and Khalifa, M. 2006. Financial and operational performance assessment: water/wastewater Egyptian utilities. Building Services Engineers Research Technology. Vol. 27 No. 4.

[31] Aguilar, Benitez, I. and Saphores, J.D. 2010. "Accountability and performance: a case study oftwo water utilities at the US-Mexico border". Water Policy. Vol. 12, pp. 203-19.

[32] Wernefelt, B. 1984. A Resource-based view of the firm. Strategic management journal, 5, 272-280

[33] Guerrini, Andrea, Giulia, dan Bettina Campedelli. 2011. Factors affecting the performance of water utility companies. International Journal of Public Sector Management Vol. 24 No. 6

[34] Tynan, N. and Kingdom, B. 2002. A Water Scorecard. Note No 242, Viewpoint Public Policy for the Private Sector, Private Sector and Infrastructure Network, The World Bank Group, Washington, DC.

[34] Dahan, Nicolas. 2005. A contribution to the conceptualization of political resources utilized in corporate political action. Journal of public affairs, 5:43-54. 